\title{
Prostate Cancer Bone Metastases Promote Both Osteolytic and Osteoblastic Activity
}

\author{
Evan T. Keller ${ }^{1}$ and Julie Brown ${ }^{2}$ \\ ${ }^{1}$ Unit for Laboratory Animal Medicine, School of Medicine, University of Michigan, Ann Arbor, \\ Michigan 48109 \\ ${ }^{2}$ Oncology Research Centre, Prince of Wales Hospital, Randwick and Department of Clinical Medicine, \\ University of New South Wales, Kensington, Sydney, New South Wales, Australia
}

\begin{abstract}
Advanced prostate cancer is frequently accompanied by the development of metastasis to bone. In the past, prostate cancer bone metastases were characterized as being osteoblastic (i.e., increasing bone density) based on radiographs. However, emerging evidence suggests that development of prostate cancer bone metastases requires osteoclastic activity in addition to osteoblastic activity. The complexities of how prostate tumor cells influence bone remodeling are just beginning to be elucidated. Prostate cancer cells produce a variety of pro-osteoblastic factors that promote bone mineralization. For example, both bone morphogenetic proteins and endothelin-1 have well recognized pro-osteoblastic activities and are produced by prostate cancer cells. In addition to factors that enhance bone mineralization prostate cancer cells produced factors that promote osteoclast activity. Perhaps the most critical proosteoclastogenic factor produced by prostate cancer cells is receptor activator of NFKB ligand (RANKL), which has been shown to be required for the development of osteoclasts. Blocking RANKL results in inhibiting prostate cancer-induced osteoclastogenesis and inhibits development and progression of prostate tumor growth in bone. These findings suggest that targeting osteoclast activity may be of therapeutic benefit. However, it remains to be defined how prostate cancer cells synchronize the combination of osteoclastic and osteoblastic activity. We propose that as the bone microenvironment is changed by the developing cancer, this in turn influences the prostate cancer cells' balance between pro-osteoclastic and pro-osteoblastic activity. Accordingly, the determination of how the prostate cancer cells and bone microenvironment crosstalk are important to elucidate how prostate cancer cells modulate bone remodeling. J. Cell. Biochem. 91: 718-729, 2004. (c) 2003 Wiley-Liss, Inc.
\end{abstract}

Key words: prostate cancer; bone metastases; metastasis; bone remodeling; OPG; BMP; ET-1; RANKL

Bone is the most frequent site of prostate carcinoma metastasis with skeletal metastases identified at autopsy in up to $90 \%$ of patients dying from prostate carcinoma [Abrams et al., 1950; Rana et al., 1993; Bubendorf et al., 2000]. Skeletal metastasis results in significant complications including bone pain, impaired

Grant sponsor: The Department of Defense Prostate Cancer Research Program; Grant number: DAMD17-03-10092; Grant sponsor: The National Institutes of Health; Grant numbers: SPORE 1 P50 CA69568, T32 RR07008.

*Correspondence to: Evan T. Keller, DVM, PhD, Rm. 5304 CCGCB, 1500 E. Medical Center Dr., University of Michigan, Ann Arbor, MI 48109-0940.

E-mail: etkeller@umich.edu

Received 30 July 2003; Accepted 1 August 2003

DOI 10.1002/jcb.10662

(c) 2003 Wiley-Liss, Inc. mobility, pathological fracture, spinal cord compression, and symptomatic hypercalcemia [Galasko, 1986; Coleman, 1997; Moul and Lipo, 1999]. Despite advances in the diagnosis and management of prostate carcinoma, advanced disease with skeletal metastasis remains incurable. Current therapeutic modalities are mostly palliative, and include hormonal therapy, pharmacological management of bone pain, radiotherapy for pain, and spinal cord compression [Szostak and Kyprianou, 2000], various chemotherapy regimens, and the use of bisphosphonates to inhibit osteoclast activity [Papapoulos et al., 2000]. In spite of the severe complications of prostate carcinoma skeletal metastasis, there has not been much advance in the therapeutic arena to prevent or diminish these lesions. It is critical that a solid understanding of the pathophysiology of prostate carcinoma skeletal metastatic process is 
developed to provide the basis for creating strategies to prevent or diminish their occurrence and associated complications.

There are many challenges that encompass determining the mechanisms that contribute to the selective development of $\mathrm{CaP}$ in bone [Lange and Vessella, 1998; Rosol, 2000]. These include mechanisms of homing to bone and tumor cell attachment at the bone endothelial site. However, once in the bone, CaP tumors have pathobiology that appears to be somewhat unique to cancer skeletal metastases. Specifically, CaP skeletal metastases are most often radiographically characterized as osteoblastic (i.e., increased mineral density at the site of the lesion) as opposed to osteolytic. Other tumors, such as breast cancer, can form osteoblastic lesions; however, these occur less frequently [Munk et al., 1997; Yamashita et al., 2000]. In spite of the radiographic osteoblastic appearance it is clear from histological evidence that $\mathrm{CaP}$ metastases form a heterogeneous mixture of osteolytic and osteoblastic lesions although osteoblastic lesions are predominant [Urwin et al., 1985; Percival et al., 1987; Berruti et al., 1996; Vinholes et al., 1996; Roudier et al., 2000]. Recent evidence shows that osteoblastic metastases form on trabecular bone at sites of previous osteoclastic resorption, and that such resorption may be required for subsequent osteoblastic bone formation [Carlin and Andriole, 2000; Zhang et al., 2001]. These findings suggest that $\mathrm{CaP}$ induces bone production through an overall increase in bone remodeling, which in the nonpathologic state is a balance between osteoclast resorption of bone, followed by osteoblast-mediated replacement of resorbed bone (reviwed in Boyce et al., 1999a; Karsenty, 2000; Parfitt, 2000). The mechanisms through which $\mathrm{CaP}$ cells promote bone mineralization or bone resorption remain poorly understood. Dissecting these mechanisms should help identify molecular targets for therapeutic approaches to prevent the damaging effects of $\mathrm{CaP}$ on the skeleton and their associated complications.

\section{THE PRO-OSTEOBLASTIC NATURE OF PROSTATE CANCER}

Histomorphometric evidence indicates that sites of prostate carcinoma bone metastases often have microscopic evidence of increased bone production including increased osteoid surface, osteoid volume, and mineralization rates [Charhon et al., 1983; Clarke et al., 1993]. The histological findings are consistent with clinical evidence that demonstrates increased systemic markers of both bone production in prostate carcinoma patients [Maeda et al., 1997; Demers et al., 2000]. However, evidence that osteoclast activity occurs is also found, which suggests that prostate carcinoma induces bone production through an overall increase in bone remodeling. In the case of prostate carcinoma, it appears the induction of osteoblast-mediated mineralization eventually outweighs the increase in osteoclast resorption resulting in an overall formation of osteoblastic lesions. Although it would seem that the increased bone production would not decrease the bones mechanical properties (i.e., its strength) it actually weakens the bone for the following reasons; mature, healthy bone is formed of lamellar bone, which consists of collagen bundles that are organized in a tightly packed linear fashion resulting in optimum bone strength. In contrast, prostate carcinoma induces production of woven bone, which is composed of loosely packed, randomly oriented collagen bundles that produce bone with suboptimal strength [Blomme et al., 1999; Rosol, 2000]. The combination of inferior bone production and underlying osteolysis leads to a predisposition to fracture.

The mechanisms through which prostate carcinoma cells promote bone mineralization remain poorly understood. However, prostate carcinoma cells produce a variety of factors that have direct or indirect osteogenic properties (Table I) (reviewed in Goltzman et al., 1992; Yoneda, 1998; Boyce et al., 1999b; Deftos, 2000). Some of these factors, such as bone morphogenetic proteins (BMP) [Harris et al., 1994; Autzen et al., 1998; Hullinger et al., 2000] and enodothlin-1 (ET-1) [Nelson et al., 1995] may directly stimulate differentiation of osteoblast precursors to mature mineral-producing osteoblasts [Kimura et al., 1992] or induce osteoblast protein production [Hullinger et al., 2000]. Other factors such as parathyroid hormonerelated protein (PTHrP) may work through inhibition of osteoblast apoptosis) [Karaplis and Vautour, 1997; Cornish et al., 1999]. Additionally, there are proteins that may work indirectly to enhance bone production, such as the serine proteases, prostate specific antigen (PSA), and urinary plasminogen activator (uPA), which can activate latent forms of osteogenic proteins, such as transforming growth 
TABLE I. Osteogenic Factors Produced by Cancer Cells

\begin{tabular}{ll}
\hline Factor & \multicolumn{1}{c}{ Reference } \\
\hline Bone morphogenetic proteins (BMP) & [Bentley et al., 1992; Hullinger et al., 2000] \\
Endothelin-1 (ET-1) & [Nelson et al., 1995; Nelson and Carducci, 2000] \\
Insulin-like growth factors (IGF) & [Perkel et al., 1990; Pirtskhalaishvili and Nelson, 2000] \\
Interleukin-1 and -6 & [Taguchi et al., 1998; Le Brun et al., 1999] \\
Osteoprotegerin (OPG) & [Guise, 2000; Honore et al., 2000] \\
Parathyroid hormone-related peptide (PTHrP) & [Karaplis and Vautour, 1997; Cornish et al., 1999] \\
Transforming growth factor- $\beta$ (TFG- $\beta$ ) & [Killian et al., 1993] \\
Urinary plasminogen activator (urokinase) & [Goltzman et al., 2000] \\
\hline
\end{tabular}

factor- $\beta$ (TFG- $\beta$ ) [Killian et al., 1993; Rabbani et al., 1997]. Finally, some molecules, such as osteoprotegerin (OPG) [Simonet et al., 1997; Guise, 2000; Honore et al., 2000; Lee et al., 2003] and ET-1 (in a dual role with its osteoblaststimulating activity) [Chiao et al., 2000] can enhance osteosclerosis through inhibiting osteoclastogenesis. Other tumor types, such as osteosarcoma, are also known to produce a variety of osteoblastic factors [Wlosarski and Reddi, 1987; Raval et al., 1996; Laitinen et al., 1998]. With such a large number of factors, it is difficult to determine which the key factor is, and most likely several of these osteogenic factors work in concert to produce maximal bone production. We will highlight two of the factors, BMP and endothelin-1 (ET-1), for which there is currently the most evidence for a role in prostate cancer-induced osteosclerosis.

BMP are members of the TFG- $\beta$ superfamily. More than $30 \mathrm{BMPs}$ have been identified to date [Ducy and Karsenty, 2000]. While originally discovered because of their ability to induced new bone formation, BMPs are now recognized to perform many functions, particularly in the role of development, such as apoptosis, differentiation, proliferation, and morphogenesis (reviewed in Hogan, 1996; Reddi, 1997; Hall and Miyake, 2000). BMPs are synthesized as large precursor molecules that undergo proteolytic cleavage to release the mature protein, which form active hetero- or homodimers [Wozney, 1992; Suzuki et al., 1997]. BMPs bind to receptors (BMPR-IA and -IB) and a BMP type II receptor (BMPR-II), which induces Smad phosphorylation [Wrana, 2000] resulting in modulation of gene regulation. Target genes of BMPs include osteoblast proteins such as OPG [Wan et al., 2001] and the osteoblastspecific transcription factor Cbfa-1 [Tsuji et al., 1998; Gori et al., 1999]. Several proteins that antagonize BMP action have been identified. For example, noggin and gremlin inhibit BMP-
$2,-4$, and -7 by binding to them [Zimmerman et al., 1996; Merino et al., 1999; Abe et al., 2000]. Furthermore, the BMPs themselves regulate their own inhibitors in an apparent negative feedback mechanism [Nifuji and Noda, 1999; Nifuji et al., 1999].

Many in vitro studies have demonstrated that BMPs induce osteogenic differentiation including the ability of BMP-7 (also called osteogenic protein-1; OP-1) to induce osteogenic differentiation of newborn rat calvarial cells and rat osteosarcoma cells [Asahina et al., 1993; Maliakal et al., 1994; Li et al., 1996]. The BMP's osteogenic properties appear to be specific to the differentiation stage of the target cells. Specifically, BMPs can induce uncommitted stem cells [Katagiri et al., 1990; Li et al., 1996; Yamaguchi et al., 1996] and myoblasts [Katagiri et al., 1997] to express osteoblast parameters such as alkaline phosphatase or osteocalcin expression [Ducy et al., 2000; Karsenty, 2000]; whereas, BMPs do not stimulate mature osteoblasts or fibroblasts [Knutsen et al., 1993; Yamaguchi et al., 1996; Kim et al., 1997; Groeneveld and Burger, 2000] to increase expression of these proteins. Examination of genetically modified mice provides further evidence of the importance of BMP in bone development. The $b m p 7$ homozygous null condition in mice is a postnatal lethal mutation and is associated with, in addition to renal and ocular abnormalities, retarded skeletal ossification [Jena et al., 1997]. In contrast, bmp 6 null mice are viable and fertile, and the skeletal elements of newborn and adult mutants are indistinguishable from wildtype [Solloway et al., 1998]. However, careful examination of skeletogenesis in late gestation embryos reveals a consistent delay in ossification strictly confined to the developing sternum. Finally, mice with mutations of the bmp5 gene have skeletal abnormalities and inefficient fracture repair [Kingsley et al., 1992]. Thus, taken together, these data provide 
evidence that BMPs are important regulators of the osteogenesis. Thus, dysregulation of their expression in the bone microenvironment would most likely impact bone remodeling.

A few studies have examined the expression of BMPs in normal and neoplastic prostate tissues. Using Northern analysis, Harris et al. [1994] examined for BMP-2, 3, 4, and 6 mRNA expression in human normal prostate and prostate carcinoma cell lines. They found that normal human prostate predominantly expressed BMP-4. The androgen-dependent non-metastatic LNCaP human prostate carcinoma cell line produced very low to undetectable levels of BMPs. Whereas, the aggressive androgen-independent PC-3 cell line expressed very high levels of BMP-3 and slightly lower levels of BMP-2, -4, and -6 compared to normal cells, but much higher than LNCaP cells. In support of these results, Weber et al. [1998], using PCR analysis, identified $16(73 \%)$ of 22 prostate carcinoma samples were positive for BMP-7 mRNA compared to eight (57\%) of 14 normal prostate tissue samples. In another PCR based analysis, Bentley et al. [1992], found that several BMPs were expressed in both benign and malignant prostate tissue and in the PC3 and DU145 prostate carcinoma cell lines. BMP-6 expression was detected in the prostate tissue of over $50 \%$ of patients with clinically defined metastatic prostate adenocarcinoma, but was not detected in non-metastatic or benign prostate samples. In another study focused on BMP-6 mRNA and protein expression, Barnes et al. [1995] observed that BMP-6 was produced by normal and neoplastic human prostate (radical prostatectomy specimens and human carcinoma cell lines DU145 and PC3). However, BMP-6 mRNA and protein expression was higher in prostate carcinoma as compared with adjacent normal prostate, with highergrade tumors (Gleason score of 6 or more) having greater BMP-6 immunostaining than the lower-grade tumors (Gleason score of 4 or less). These results were consistent with a later study by Hamdy et al. [1997], who reported that BMP-6 mRNA expression was detected exclusively in malignant epithelial cells in 20 of 21 patients $(95 \%)$ with metastases, in 2 of 11 patients (18\%) with localized cancer, and undetectable in eight benign samples. Futhermore, BMP-7 mRNA levels were found to be higher in prostate cancer skeletal metastases than in bone itself [Masuda et al., 2003]. In addition to
BMPs, there have been several reports on prostate carcinoma expression of BMPR, it appears that as prostate carcinoma progress, the cells down-regulate their own expression of BMPRs [Ide et al., 1997a; Kim et al., 2000], which may be a protective mechanism as it has been demonstrated that BMP-2 can inhibit prostate carcinoma cell proliferation [Ide et al., 1997b]. Taken together, these observations demonstrate that prostate carcinoma cells produce increasing levels of BMPs as they progress to a more aggressive phenotype and suggest that the upregulation of BMP expression in prostate carcinoma cells localized in the bone is a critical component of the mechanism of development of osteoblastic lesions at prostate carcinoma metastatic sites.

\section{Endothelins}

Osteoblastic metastases occur in most prostate cancers and frequently in other common malignancies, such as breast cancer [Guise and Mundy, 1998]. Many tumor-associated factors have been proposed as mediators of the disorganized new bone formation at sites of metastases, including insulin-like growth factors (IGF)-1 and -2, transforming growth factor (TGF) $\beta$, prostate-specific antigen (PSA), urokinase-type plasminogen activator (UPA), fibroblast growth factors (FGF)-1 and -2, BMPs, and endothelin-1 (ET-1) [Achbarou et al., 1994; Thalmann et al., 1994; Nelson et al., 1995, 1996, 1999; Gingrich et al., 1996].

Accumulating evidence implicate ET- 1 in the pathogenesis of osteoblastic metastases. Yanagisawa et al. [1988] originally purified ET-1 from endothelial cells. ET-1 is a potent vasoconstrictor, belonging to a family of three 21-aminoacid peptides, with a variety of functions [La and Reid, 1995]. The endothelins mediate their effects through endothelin A (ETA) and endothelin B (ETB) receptors. ETA receptors bind ET-1 with ten times greater affinity than ET-3 while the $B$ receptor binds all three endothelins with equal affinity.

ET-1 has multiple effects on bone cells. It stimulates mitogenesis in osteoblasts, which express both ETA and ETB receptors [Takuwa et al., 1990; Stern et al., 1995]. ET-1 decreases osteoclastic bone resorption and osteoclast motility [Alam et al., 1992]. Immunohistochemistry of bone detected ET-1 in osteocytes, osteoblasts, and osteoclasts [Sasaki and Hong, 1993a,b]. 
Nelson et al. [1995] suggested the link between osteoblastic metastases, prostate cancer, and ET-1. They demonstrated that plasma ET-1 concentrations were significantly higher in men with advanced, hormone-refractory prostate cancer with bone metastases compared to men with organ-confined prostate cancer or normal controls [Nelson et al., 1995]. However, ET-1 concentrations were not correlated to tumor burden in bone or to serum prostatespecific antigen (PSA) concentrations.

Prostatic epithelium produces ET-1, and high-affinity receptors are present throughout the prostate gland [Nelson et al., 1995, 1996, 1999]. A majority of prostate cancers at primary as well as at metastatic sites express ET-1. Exogenous ET-1 increases the proliferation of prostate cancer as well as augmenting the mitogenic effects of IGF-1, -2; platelet-derived growth factor (PDGF); epidermal growth factor (EGF) and FGF-2 on prostate cancer cells. These effects are mediated via ETA receptors [Nelson et al., 1996]. ETB receptor expression was decreased in cancerous compared to normal prostate and was low in the prostate cancer cell lines PC3, DU 145, and LNCaP.

Breast cancers also express ET- 1 and are the next most common tumor to cause osteoblastic metastases. Human breast cancer cells MCF-7, T47-D, and MDA-MB-231 have been shown to express the endothelin-processing enzyme necessary to convert preproET-1 to ET-1 [Patel and Schrey, 1995; Schrey and Patel, 1995; Yorimitsu et al., 1995; Patel et al., 1997]. Thus, substantial data implicate ET-1 in the pathogenesis of osteoblastic metastases due to prostate and breast cancers. However, a direct demonstration of a causal role for ET-1 in bone metastasis has not previously been reported. Questions remain about whether ET-1 has effects on bone formation in vivo, about the specificity of its effects, and about whether the increase in ET-1 observed in patients with prostate cancer represents a causative factor.

The bulk of evidence for a pro-osteoblastic metastatic effect of ET-1 has been derived from breast cancer skeletal metastases. Recent evidence indicates that breast cancer lines (ZR-751, MCF-7, and T47D) all cause osteoblastic metastases in female nude mice and produce ET-1 [Yin et al., 2000]. Conditioned media from these cell lines, as well as exogenous ET-1, stimulated osteoblast proliferation and new bone formation in cultures of mouse calvariae.
These effects were inhibited by nonselective and ETA, but not ETB, receptor antagonists. Mice inoculated with ZR-75-1 and treated with oral ABT-627, a selective ETA receptor antagonist (2 or $20 \mathrm{mg} / \mathrm{kg} /$ day), had significantly fewer bone metastases compared with untreated ZR75-1-mice. Bone histomorphometry revealed that the untreated ZR-75-1-mice had greater total bone area as well as new bone area compared with ABT-627-treated ZR-75-1-mice at either dose. Tumor burden in bone was significantly less in ABT-627-treated mice. In contrast, there was no effect of ABT-627 on osteolytic bone metastases caused by ET-1negative breast cancer, MDA-MB-231. ETA and ETB expression, determined by RT-PCR, revealed that ZR-75-1 expressed neither ETA nor ETB while MDA-MB-231 expressed both. There was no effect of ABT-627 on (1) in vitro growth of ZR-75-1 or MDA-MB-231 or (2) in vivo growth of ZR-75-1 or MDA-MB-231 mammary fat pad tumors. These data indicate that the effects of ABT-627 to inhibit osteoblastic metastases are not direct effects on these tumor cells, but rather directed against the osteoblastic response of tumor-produced ET-1. Collectively these data suggest that tumor-produced ET-1 likely has a major role in the establishment of osteoblastic bone metastases by stimulating osteoblast proliferation and new bone formation. In terms of prostate cancer, atrasentan, an antagonist of ET-1 receptor A, partially reversed primary murine osteoblast proliferation induced by prostate cancer cells [Fizazi et al., 2003], suggesting that ET-1 may play a role in vivo. Blockade of the ETA receptor may be useful for prevention and the treatment of osteoblastic bone metastases due to breast or prostate cancer.

In addition to production of pro-osteoblastic factors, prostate cancer cells themselves gain an osteoblast-like phenotype. The initial evidence for this possibility was shown in a study that demonstrated $\mathrm{C} 4-2 \mathrm{~B}$ prostate cancer cells mineralized in vitro [Lin et al., 2001]. Furthermore, increased nuclear expression of the bonespecific transcription factor Cbfa1 (also known as Runx2, CCD, AML3, CCD1, OSF2) was found in the $\mathrm{C} 4-2 \mathrm{~B}$ cells and blocking Cbfa1 activity decreased the ability of $\mathrm{C} 4-2 \mathrm{~B}$ cells to mineralize in vitro. Additionally, mRNA and protein of the osteoblast-active transcription factor Cbfa1 were detected in prostate cancer tissues and cell lines [Brubaker et al., 2003]. Finally, a 
specific Cbfa1: OSE2 (an osteoblast-specific cisacting element present in the osteocalcin promoter) complex could be formed with PC-3 nuclear extracts. These data suggest that prostate cancer cells may promote osteosclerosis directly, although direct evidence of this has not been provided to date.

In summary, a variety of factors may promote the osteoblastic nature of prostate cancer bone metastases. Most likely no individual factor is responsible for prostate cancer-induced osteosclerosis, but rather several factors work in concert to induce both osteoblastogenesis and osteoblast activity.

\section{THE PRO-OSTEOLYTIC NATURE OF PROSTATE CANCER}

In healthy adults, the regulated destruction (resorption or lysis) of normal lamellar bone matrix by large multinucleated osteoclasts is tightly coupled to the consequent formation of new bone by osteoblasts, such that lysis and formation are balanced (reviewed in Manolagas and Jilka, 1995). However, in prostate cancer bone metastasis, bone lysis is stimulated at sites of tumor growth and excess woven bone is synthesized [Clarke et al., 1991]. This results in a general increase in both bone turnover and volume, although woven bone has less collagen and therefore less tensile strength than normal and is more susceptible to fracture. Evidence suggests that lysis is a prerequisite for the establishment of tumor cells in bone [Roland, 1958; Nielsen et al., 1991], therefore understanding the regulation of bone resorption may suggest mechanisms through which tumors can develop in bone and may indicate novel therapeutic targets.

In normal bone, osteoblastic cells regulate osteoclastogenesis and osteoclast activity by interacting with mononuclear hematopoietic osteoclast precursors [Roodman, 1996]. The molecular mediators of this interaction were shown to be the osteoblast-expressed proteins, $\mathrm{OPG}$ and receptor activator of $\mathrm{NF} \kappa \mathrm{B}$ ligand (RANKL). Binding of RANKL to the osteoclast precursor-expressed RANK initiates a cascade of intracellular signals that culminates in the acquisition and activation of the osteoclast phenotype [Lacey et al., 1998; Yasuda et al., 1998a]. The absolute requirement of this interaction for osteoclastogenesis was shown by the generation of transgenic rankl $-/-$ and rank -/ - mice that developed severely hyperdense bones due to an absence of osteoclasts [Dougall et al., 1999; Kong et al., 1999]. Furthermore, administration of soluble extracellular RANKL to mice resulted in hypercalcemia and reduced bone volume, concomitant with a doubling of osteoclast size [Lacey et al., 1998]. The soluble glycoprotein OPG regulates excessive bone resorption by acting as a soluble decoy receptor for RANKL [Simonet et al., 1997], and therefore neutralizes its interaction with RANK, abrogating osteoclast formation, activation, and survival in vitro [Yasuda et al., 1998a,b] and in vivo [Lacey et al., 1998]. The crucial role of OPG in bone remodeling was demonstrated using transgenic opg $-/-$ mice, which showed uncontrolled bone resorption and severe osteoporosis [Mizuno et al., 1998]. These studies suggest that the balance between RANKL and OPG determines the extent of bone resorption, in that a relative decrease in OPG results in excessive resorption and a relative increase in OPG inhibits resorption.

Recent work has shown that the expression of OPG, RANKL, and/or RANK is dysregulated in a number of cancers in bone, including osteoclastoma [Atkins et al., 2000] and prostate cancer [Brown et al., 2001], suggesting that these proteins may be involved in tumormediated bone destruction. Breast cancer cell lines were shown to express OPG and RANK but not RANKL [Thomas et al., 1999]. However, coculture with hematopoietic bone marrow cells and osteoblasts resulted in a net increase in RANKL expression, suggesting an indirect mechanism through which localized bone lysis may occur in breast cancer bone metastasis, by activation of osteoclast precursors [Thomas et al., 1999]. This was supported using a murine in vitro model in which interactions between mouse breast cancer cells and bone marrow cells similarly resulted in a net increase in RANKL activity [Chikatsu et al., 2000]. The cancerstromal interaction is also critical in multiple myeloma, where co-culture produced a net increase in RANKL expression and in osteoclastogenesis that was inhibited by addition of soluble RANK [Pearse et al., 2001]. The production of active soluble RANKL by prostate cancer cells in vitro has been implicated as a mechanism through which prostate cancer cells can directly initiate osteoclastogenesis and therefore stimulate bone resorption [Zhang et al., 2001]. 
Several exciting and provocative studies have examined the therapeutic uses of soluble RANK and OPG in the treatment of hematological and solid tumors in bone. As a fusion protein with human IgG, RANK has proven efficacious in the inhibition of bone resorption in a mouse model of humoral hypercalcemia of malignancy as induced by PTHrP administration [Oyajobi et al., 2001], and in the prevention of myeloma-induced osteoclastic bone destruction in a SCID-human model [Pearse et al., 2001]. In vitro experiments treating osteoclastomaderived cells with OPG reduced the number of mature osteoclasts and inhibited bone resorption [Atkins et al., 2001]. Dramatic decreases in the numbers of mature osteoclasts and in the size and/or number of lesions in bone were observed following the treatment with OPG of mice carrying human breast cancer cells [Morony et al., 2001], murine multiple myeloma [Croucher et al., 2001], and human prostate cancer cells [Zhang et al., 2001]. In human prostate cancer cells, OPG has been shown to be a survival factor through its ability to inhibit TRAIL-mediated apoptosis [Holen et al., 2002]. Importantly, treatment with OPG has also been demonstrated to block pain-related behavior in mice carrying bone cancers [Honore et al., 2000; Luger et al., 2001]. Overall, these studies suggest that in bone metastatic tumors, inhibition of the primary resorptive stage may be sufficient to inhibit tumor establishment and halt progression of disease, even in those tumors that have primarily an osteoblastic phenotype. However, one prostate cancer cell line, LAPC-9, was demonstrated to not produce RANKL, but rather produced OPG [Lee et al., 2003]. This cell line produced osteoblastic tumor when injected into mouse tibia. The osteoblastic tumors did not appear to have osteoclastic activity during their early development phase, but developed osteoclastic activity by 6 weeks. These results bring into question the requirement for osteoclastic activity for the initial establishment of the prostate tumors in bone. Further support for this possibility was the observation that a bisphosphonate, zoledronic acid, did not diminish development of LAPC-9 cells injected into the tibia of mice; whereas it did decrease development of osteolytic PC-3 cells [Lee et al., 2002 ]. While studies are at an early stage at present, it appears that therapeutic targeting of the OPG/RANKL/RANK proteins holds great promise for at least therapy of bone metastases and perhaps may prevent establishment and progression of bone metastases.

\section{A MODEL FOR PROSTATE CANCER'S EFFECT ON BONE REMODELING}

From these observations, we propose a model for how prostate cancer cells influence bone remodeling. In order to account the apparently contrasting ability of prostate cancer cells to be both pro-osteoblastic and pro-osteolytic several aspects of the metastases need to be taken into account. These include the bone microenvironment the tumor cells are exposed to (reviewed in Cooper et al., 2003) and the temporal progression of the cancer. Based on these parameters, we propose (Fig. 1) that when prostate cancer cells metastasize to bone, they initially induce osteoclastogenesis and bone resorption. As bone is broken down, the extracellular matrix releases a variety of growth factors (reviewed in Guise and Mundy, 1998 \#8470) that act in a paracrine fashion on the prostate tumor cells and diminish their ability to induce osteoclastogenesis, while promoting their ability to grow and induce osteoblastic activity. This model is consistent with various observations including the ability of anti-osteoclastogenic agents to inhibit establishment of tumor in bone and the mixture of osteolytic and osteoblastic features identified in clinical prostate cancer bone metastases, even within one patient. Unfortunately, proving this hypothesis is challenging for several reasons including that there are currently no animal models that recapitulate spontaneous clinical prostate cancer bone metastases.

The biology of prostate cancer bone metastasis has received increased attention in the last few years. The resulting data point to a complicated system with multiple interacting proteins and pathways. Thus, while dissecting individual protein factor pathways (e.g., BMPs) is important, eventually a synthesis of how these various pathways work together to impact bone remodeling will be necessary to provide a comprehensive understanding of the biology of prostate cancer bone metastases. Along this line of thought, clearly the bone microenvironment, which is under constant change from the influence of tumor cells, plays a role in the establishment and progression of prostate cancer bone metastases. Thus, future studies are needed to define the complex cross-talk between 


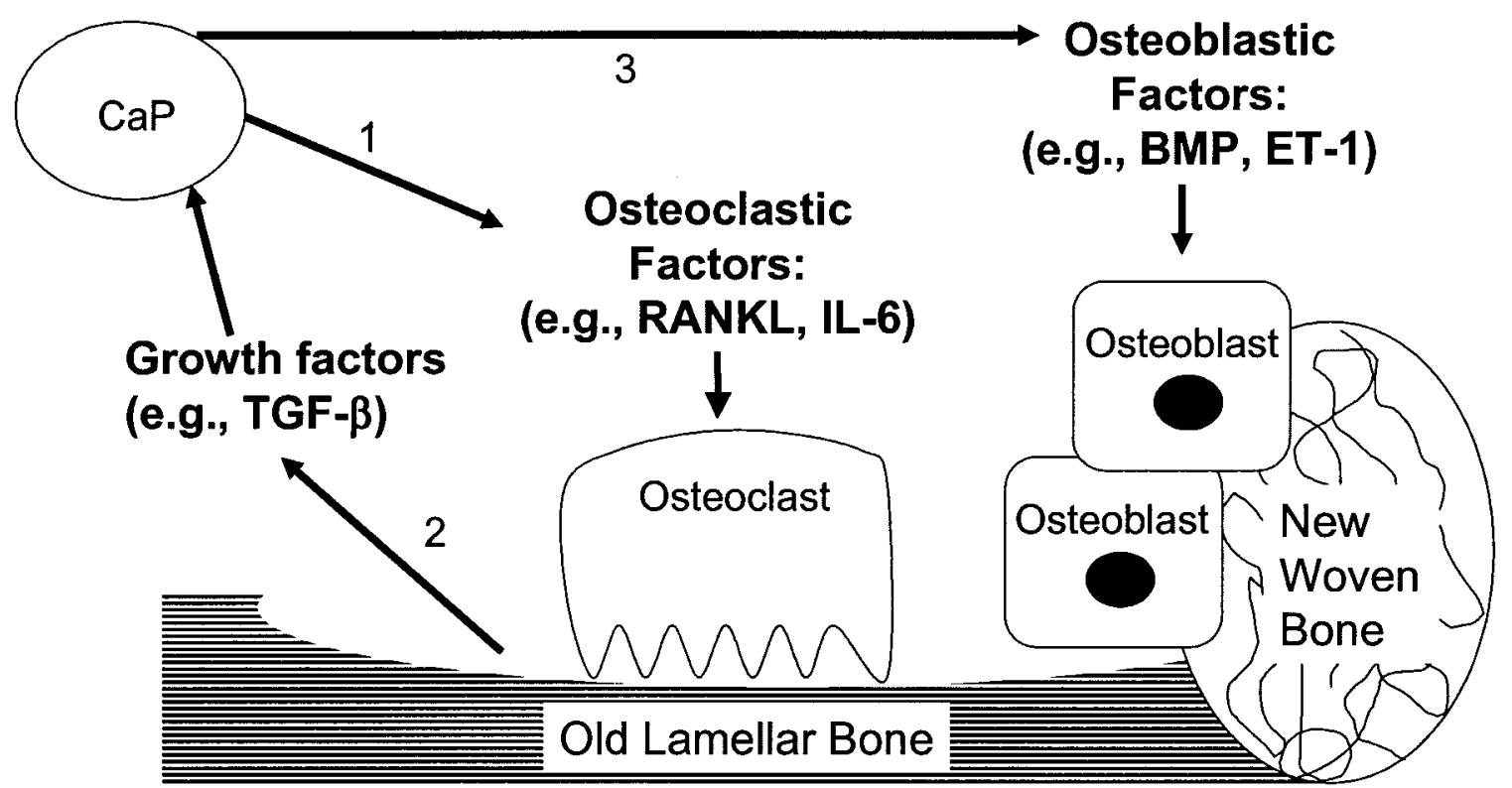

Fig. 1. Model for how prostate cancer induces bone remodeling. The prostate cancer cells initially (1) induce osteoclastogenesis and resorption of mature lamellar bone. As the bone matrix is destroyed, it releases growth factors (2) that induce prostate cancer cells' growth and alter their phenotype. The changing bone microenvironment, enhances the prostate cancer cells'

the bone microenvironment and the prostate cancer cells. In order to reach these goals, development of appropriate research tools, such as animal models and cells lines, that recapitulate human prostate cancer bone metastasis biology, are needed to advance the field.

\section{REFERENCES}

Abe E, Yamamoto M, Taguchi Y, Lecka-Czernik B, O’Brien CA, Economides AN, Stahl N, Jilka RL, Manolagas SC. 2000. Essential requirement of BMPs-2/4 for both osteoblast and osteoclast formation in murine bone marrow cultures from adult mice: Antagonism by noggin. J Bone Miner Res 15:663-673.

Abrams H, Spiro R, Goldstein N. 1950. Metastases in carcinoma. Cancer 3:74-85.

Achbarou A, Kaiser S, Tremblay G, Ste-Marie LG, Brodt P, Goltzman D, Rabbani SA. 1994. Urokinase overproduction results in increased skeletal metastasis by prostate cancer cells in vivo. Cancer Res 54:2372-2377.

Alam AS, Gallagher A, Shankar V, Ghatei MA, Datta HK, Huang CL, Moonga BS, Chambers TJ, Bloom SR, Zaidi M. 1992. Endothelin inhibits osteoclastic bone resorption by a direct effect on cell motility: Implications for the vascular control of bone resorption. Endocrinology 130: 3617-3624.

Asahina I, Sampath TK, Nishimura I, Hauschka PV. 1993. Human osteogenic protein-1 induces both chondroblastic and osteoblastic differentiation of osteoprogenitor cells derived from newborn rat calvaria. J Cell Biol 123:921933. production of osteoblastic factors (3) resulting in production of woven bone. BMP, bone morphogenetic protein; $\mathrm{CaP}$, prostate cancer cell; ET-1, endothelin-1; IL-6, interleukin-6; RANKL, receptor activator of NFאB ligand; TGF- $\beta$, transforming growth factor $\beta$.

Atkins GJ, Haynes DR, Graves SE, Evdokiou A, Hay S, Bouralexis S, Findlay DM. 2000. Expression of osteoclast differentiation signals by stromal elements of giant cell tumors. J Bone Miner Res 15:640-649.

Atkins GJ, Bouralexis S, Haynes DR, Graves SE, Geary SM, Evdokiou A, Zannettino AC, Hay S, Findlay DM. 2001. Osteoprotegerin inhibits osteoclast formation and bone resorbing activity in giant cell tumors of bone. Bone 28:370-377.

Autzen P, Robson CN, Bjartell A, Malcolm AJ, Johnson MI, Neal DE, Hamdy FC. 1998. Bone morphogenetic protein 6 in skeletal metastases from prostate cancer and other common human malignancies. Br J Cancer 78:12191223.

Barnes J, Anthony CT, Wall N, Steiner MS. 1995. Bone morphogenetic protein-6 expression in normal and malignant prostate. World J Urol 13:337-343.

Bentley H, Hamdy FC, Hart KA, Seid JM, Williams JL, Johnstone D, Russell RG. 1992. Expression of bone morphogenetic proteins in human prostatic adenocarcinoma and benign prostatic hyperplasia. $\mathrm{Br} \mathrm{J}$ Cancer 66:1159-1163.

Berruti A, Piovesan A, Torta M, Raucci CA, Gorzegno G, Paccotti P, Dogliotti L, Angeli A. 1996. Biochemical evaluation of bone turnover in cancer patients with bone metastases: Relationship with radiograph appearances and disease extension. Br J Cancer 73:15811587.

Blomme EA, Dougherty KM, Pienta KJ, Capen CC, Rosol TJ, McCauley LK. 1999. Skeletal metastasis of prostate adenocarcinoma in rats: Morphometric analysis and role of parathyroid hormone-related protein. Prostate 39: 187-197. 
Boyce BF, Hughes DE, Wright KR, Xing L, Dai A. 1999a. Recent advances in bone biology provide insight into the pathogenesis of bone diseases. Lab Invest 79:83-94.

Boyce BF, Yoneda T, Guise TA. 1999b. Factors regulating the growth of metastatic cancer in bone. Endocr Relat Cancer 6:333-347.

Brown JM, Corey E, Lee ZD, True LD, Yun TJ, Tondravi M, Vessella RL. 2001. Osteoprotegerin and rank ligand expression in prostate cancer. Urology 57:611-616.

Brubaker KD, Vessella RL, Brown LG, Corey E. 2003. Prostate cancer expression of runt-domain transcription factor Runx2, a key regulator of osteoblast differentiation and function. Prostate 56:13-22.

Bubendorf L, Schopfer A, Wagner U, Sauter G, Moch H, Willi N, Gasser TC, Mihatsch MJ. 2000. Metastatic patterns of prostate cancer: An autopsy study of 1,589 patients. Hum Pathol 31:578-583.

Carlin BI, Andriole GL. 2000. The natural history, skeletal complications, and management of bone metastases in patients with prostate carcinoma. Cancer 88:2989-2994.

Charhon SA, Chapuy MC, Delvin EE, Valentin-Opran A, Edouard CM, Meunier PJ. 1983. Histomorphometric analysis of sclerotic bone metastases from prostatic carcinoma special reference to osteomalacia. Cancer 51:918924.

Chiao JW, Moonga BS, Yang YM, Kancherla R, Mittelman A, Wu-Wong JR, Ahmed T. 2000. Endothelin-1 from prostate cancer cells is enhanced by bone contact which blocks osteoclastic bone resorption. Br J Cancer 83:360365.

Chikatsu N, Takeuchi Y, Tamura Y, Fukumoto S, Yano K, Tsuda E, Ogata E, Fujita T. 2000. Interactions between cancer and bone marrow cells induce osteoclast differentiation factor expression and osteoclast-like cell formation in vitro. Biochem Biophys Res Commun 267:632637.

Clarke NW, McClure J, George NJ. 1991. Morphometric evidence for bone resorption and replacement in prostate cancer. Br J Urol 68:74-80.

Clarke NW, McClure J, George NJ. 1993. Osteoblast function and osteomalacia in metastatic prostate cancer. Eur Urol 24:286-290.

Coleman RE. 1997. Skeletal complications of malignancy. Cancer 80:1588-1594.

Cooper CR, Chay CH, Gendernalik JD, Lee HL, Bhatia J, Taichman RS, McCauley LK, Keller ET, Pienta KJ. 2003. Stromal factors involved in prostate carcinoma metastasis to bone. Cancer 97:739-747.

Cornish J, Callon KE, Lin C, Xiao C, Moseley JM, Reid IR. 1999. Stimulation of osteoblast proliferation by Cterminal fragments of parathyroid hormone-related protein. J Bone Miner Res 14:915-922.

Croucher PI, Shipman CM, Lippitt J, Perry M, Asosingh K, Hijzen A, Brabbs AC, van Beek EJ, Holen I, Skerry TM, Dunstan CR, Russell GR, Van Camp B, Vanderkerken K. 2001. Osteoprotegerin inhibits the development of osteolytic bone disease in multiple myeloma. Blood 98:35343540 .

Deftos LJ. 2000. Prostate carcinoma: Production of bioactive factors. Cancer 88:3002-3008.

Demers LM, Costa L, Lipton A. 2000. Biochemical markers and skeletal metastases. Cancer 88:2919-2926.

Dougall WC, Glaccum M, Charrier K, Rohrbach K, Brasel K, De Smedt T, Daro E, Smith J, Tometsko ME,
Maliszewski CR, Armstrong A, Shen V, Bain S, Cosman D, Anderson D, Morrissey PJ, Peschon JJ, Schuh J. 1999. RANK is essential for osteoclast and lymph node development. Genes Dev 13:2412-2424.

Ducy P, Karsenty G. 2000. The family of bone morphogenetic proteins. Kidney Int 57:2207-2214.

Ducy P, Schinke T, Karsenty G. 2000. The osteoblast: A sophisticated fibroblast under central surveillance. Science 289:1501-1504.

Fizazi K, Yang J, Peleg S, Sikes CR, Kreimann EL, Daliani D, Olive M, Raymond KA, Janus TJ, Logothetis CJ, Karsenty G, Navone NM. 2003. Prostate cancer cellsosteoblast interaction shifts expression of growth/survival-related genes in prostate cancer and reduces expression of osteoprotegerin in osteoblasts. Clin Cancer Res 9:2587-2597.

Galasko CS. 1986. Skeletal metastases. Clin Orthop 210: $18-30$.

Gingrich JR, Barrios RJ, Morton RA, Boyce BF, DeMayo FJ, Finegold MJ, Angelopoulou R, Rosen JM, Greenberg NM. 1996. Metastatic prostate cancer in a transgenic mouse. Cancer Res 56:4096-4102.

Goltzman D, Bolivar I, Rabbani SA. 1992. Studies on the pathogenesis of osteoblastic metastases by prostate cancer. Adv Exp Med Biol 324:165-171.

Goltzman D, Karaplis AC, Kremer R, Rabbani SA. 2000. Molecular basis of the spectrum of skeletal complications of neoplasia. Cancer 88:2903-2908.

Gori F, Thomas T, Hicok KC, Spelsberg TC, Riggs BL. 1999. Differentiation of human marrow stromal precursor cells: Bone morphogenetic protein-2 increases OSF2/ CBFA1, enhances osteoblast commitment, and inhibits late adipocyte maturation. J Bone Miner Res 14:15221535.

Groeneveld EH, Burger EH. 2000. Bone morphogenetic proteins in human bone regeneration. Eur J Endocrinol 142:9-21.

Guise TA. 2000. Molecular mechanisms of osteolytic bone metastases. Cancer 88:2892-2898.

Guise TA, Mundy GR. 1998. Cancer and bone. Endocr Rev 19:18-54.

Hall BK, Miyake T. 2000. All for one and one for all: Condensations and the initiation of skeletal development. Bioessays 22:138-147.

Hamdy FC, Autzen P, Robinson MC, Horne CH, Neal DE, Robson CN. 1997. Immunolocalization and messenger RNA expression of bone morphogenetic protein- 6 in human benign and malignant prostatic tissue. Cancer Res 57:4427-4431.

Harris SE, Harris MA, Mahy P, Wozney J, Feng JQ, Mundy GR. 1994. Expression of bone morphogenetic protein messenger RNAs by normal rat and human prostate and prostate cancer cells. Prostate 24:204-211.

Hogan BL. 1996. Bone morphogenetic proteins in development. Curr Opin Genet Dev 6:432-438.

Holen I, Croucher PI, Hamdy FC, Eaton CL. 2002. Osteoprotegerin (OPG) is a survival factor for human prostate cancer cells. Cancer Res 62:1619-1623.

Honore P, Luger NM, Sabino MA, Schwei MJ, Rogers SD, Mach DB, O'Keefe PF, Ramnaraine ML, Clohisy DR, Mantyh PW. 2000. Osteoprotegerin blocks bone cancerinduced skeletal destruction, skeletal pain, and painrelated neurochemical reorganization of the spinal cord. Nat Med 6:521-528. 
Hullinger TG, Taichman RS, Linseman DA, Somerman MJ. 2000. Secretory products from PC-3 and MCF-7 tumor cell lines upregulate osteopontin in MC3T3-E1 cells. J Cell Biochem 78:607-616.

Ide H, Katoh M, Sasaki H, Yoshida T, Aoki K, Nawa Y, Osada Y, Sugimura T, Terada M. 1997a. Cloning of human bone morphogenetic protein type IB receptor (BMPR-IB) and its expression in prostate cancer in comparison with other BMPRs published erratum appears in Oncogene 1997 Aug 28;15(9):1121. Oncogene 14:1377-1382.

Ide H, Yoshida T, Matsumoto N, Aoki K, Osada Y, Sugimura T, Terada M. 1997b. Growth regulation of human prostate cancer cells by bone morphogenetic protein-2. Cancer Res 57:5022-5027.

Jena N, Martin-Seisdedos C, McCue P, Croce CM. 1997. BMP7 null mutation in mice: Developmental defects in skeleton, kidney, and eye. Exp Cell Res 230:28-37.

Karaplis AC, Vautour L. 1997. Parathyroid hormonerelated peptide and the parathyroid hormone/parathyroid hormone-related peptide receptor in skeletal development. Curr Opin Nephrol Hypertens 6:308313.

Karsenty G. 2000. Bone formation and factors affecting this process. Matrix Biol 19:85-89.

Katagiri T, Yamaguchi A, Ikeda T, Yoshiki S, Wozney JM, Rosen V, Wang EA, Tanaka H, Omura S, Suda T. 1990. The non-osteogenic mouse pluripotent cell line, $\mathrm{C} 3 \mathrm{H} 10 \mathrm{~T} 1 / 2$, is induced to differentiate into osteoblastic cells by recombinant human bone morphogenetic protein-2. Biochem Biophys Res Commun 172:295-299.

Katagiri T, Akiyama S, Namiki M, Komaki M, Yamaguchi A, Rosen V, Wozney JM, Fujisawa-Sehara A, Suda T. 1997. Bone morphogenetic protein-2 inhibits terminal differentiation of myogenic cells by suppressing the transcriptional activity of MyoD and myogenin. Exp Cell Res 230:342-351.

Killian CS, Corral DA, Kawinski E, Constantine RI. 1993. Mitogenic response of osteoblast cells to prostate-specific antigen suggests an activation of latent TGF-beta and a proteolytic modulation of cell adhesion receptors. Biochem Biophys Res Commun 192:940-947.

Kim KJ, Itoh T, Kotake S. 1997. Effects of recombinant human bone morphogenetic protein-2 on human bone marrow cells cultured with various biomaterials. J Biomed Mater Res 35:279-285.

Kim IY, Lee DH, Ahn HJ, Tokunaga H, Song W, Devereaux LM, Jin D, Sampath TK, Morton RA. 2000. Expression of bone morphogenetic protein receptors type-IA, -IB, and -II correlates with tumor grade in human prostate cancer tissues. Cancer Res 60:2840-2844.

Kimura G, Sugisaki Y, Masugi Y, Nakazawa N. 1992. Calcification in human osteoblasts cultured in medium conditioned by the prostatic cancer cell line PC-3 and prostatic acid phosphatase. Urol Int 48:25-30.

Kingsley DM, Bland AE, Grubber JM, Marker PC, Russell LB, Copeland NG, Jenkins NA. 1992. The mouse short ear skeletal morphogenesis locus is associated with defects in a bone morphogenetic member of the TGF beta superfamily. Cell 71:399-410.

Knutsen R, Wergedal JE, Sampath TK, Baylink DJ, Mohan S. 1993. Osteogenic protein-1 stimulates proliferation and differentiation of human bone cells in vitro. Biochem Biophys Res Commun 194:1352-1358.
Kong YY, Boyle WJ, Penninger JM. 1999. Osteoprotegerin ligand: A common link between osteoclastogenesis, lymph node formation, and lymphocyte development. Immunol Cell Biol 77:188-193.

La M, Reid JJ. 1995. Endothelin-1 and the regulation of vascular tone. Clin Exp Pharmacol Physiol 22:315-323.

Lacey DL, Timms E, Tan HL, Kelley MJ, Dunstan CR, Burgess T, Elliott R, Colombero A, Elliott G, Scully S, Hsu H, Sullivan J, Hawkins N, Davy E, Capparelli C, Eli A, Qian YX, Kaufman S, Sarosi I, Shalhoub V, Senaldi G, Guo J, Delaney J, Boyle WJ. 1998. Osteoprotegerin ligand is a cytokine that regulates osteoclast differentiation and activation. Cell 93:165-176.

Laitinen M, Marttinen A, Aho AJ, Lindholm TS. 1998. Bone morphogenetic protein in bone neoplasms: Comparison of different detection methods. Eur Surg Res 30:168-174.

Lange PH, Vessella RL. 1998. Mechanisms, hypotheses, and questions regarding prostate cancer micrometastases to bone. Cancer Metastasis Rev 17:331-336.

Le Brun G, Aubin P, Soliman H, Ropiquet F, Villette JM, Berthon P, Creminon C, Cussenot O, Fiet J. 1999 Upregulation of endothelin 1 and its precursor by IL1beta, TNF-alpha, and TGF-beta in the PC3 human prostate cancer cell line. Cytokine 11:157-162.

Lee YP, Schwarz EM, Davies M, Jo M, Gates J, Zhang X, Wu J, Lieberman JR. 2002. Use of zoledronate to treat osteoblastic versus osteolytic lesions in a severe-combined-immunodeficient mouse model. Cancer Res 62: 5564-5570.

Lee Y, Schwarz E, Davies M, Jo M, Gates J, Wu J, Zhang X, Lieberman JR. 2003. Differences in the cytokine profiles associated with prostate cancer cell induced osteoblastic and osteolytic lesions in bone. J Orthop Res 21: 62-72.

Li IW, Cheifetz S, McCulloch CA, Sampath KT, Sodek J. 1996. Effects of osteogenic protein-1 (OP-1, BMP-7) on bone matrix protein expression by fetal rat calvarial cells are differentiation stage specific. J Cell Physiol 169: $115-125$.

Lin DL, Tarnowski CP, Zhang J, Dai J, Rohn E, Patel AH, Morris MD, Keller ET. 2001. Bone metastatic LNCaPderivative $\mathrm{C} 4-2 \mathrm{~B}$ prostate cancer cell line mineralizes in vitro. Prostate 47:212-221.

Luger NM, Honore P, Sabino MA, Schwei MJ, Rogers SD, Mach DB, Clohisy DR, Mantyh PW. 2001. Osteoprotegerin diminishes advanced bone cancer pain. Cancer Res 61:4038-4047.

Maeda H, Koizumi M, Yoshimura K, Yamauchi T, Kawai T, Ogata E. 1997. Correlation between bone metabolic markers and bone scan in prostatic cancer. J Urol 157:539-543.

Maliakal JC, Asahina I, Hauschka PV, Sampath TK. 1994. Osteogenic protein-1 (BMP-7) inhibits cell proliferation and stimulates the expression of markers characteristic of osteoblast phenotype in rat osteosarcoma (17/2.8) cells. Growth Factors 11:227-234.

Manolagas SC, Jilka RL. 1995. Bone marrow, cytokines, and bone remodeling. Emerging insights into the pathophysiology of osteoporosis. New Engl J Med 332:305311.

Masuda H, Fukabori Y, Nakano K, Takezawa Y, T CS, Yamanaka H. 2003. Increased expression of bone morphogenetic protein-7 in bone metastatic prostate cancer. Prostate 54:268-274. 
Merino R, Rodriguez-Leon J, Macias D, Ganan Y, Economides AN, Hurle JM. 1999. The BMP antagonist gremlin regulates outgrowth, chondrogenesis, and programmed cell death in the developing limb. Development 126:5515-5522.

Mizuno A, Amizuka N, Irie K, Murakami A, Fujise N, Kanno T, Sato Y, Nakagawa N, Yasuda H, Mochizuki S, Gomibuchi T, Yano K, Shima N, Washida N, Tsuda E, Morinaga T, Higashio K, Ozawa H. 1998. Severe osteoporosis in mice lacking osteoclastogenesis inhibitory factor/osteoprotegerin. Biochem Biophys Res Commun 247:610-615.

Morony S, Capparelli C, Sarosi I, Lacey DL, Dunstan CR, Kostenuik PJ. 2001. Osteoprotegerin inhibits osteolysis and decreases skeletal tumor burden in syngeneic and nude mouse models of experimental bone metastasis. Cancer Res 61:4432-4436.

Moul JW, Lipo DR. 1999. Prostate cancer in the late 1990s: Hormone refractory disease options. Urol Nurs 19:12531; quiz 132-3.

Munk PL, Poon PY, O'Connell JX, Janzen D, Coupland D, Kwong JS, Gelmon K, Worsley D. 1997. Osteoblastic metastases from breast carcinoma with false-negative bone scan. Skeletal Radiol 26:434-437.

Nelson JB, Carducci MA. 2000. The role of endothelin-1 and endothelin receptor antagonists in prostate cancer. BJU Int 85(Suppl 2):45-48.

Nelson JB, Hedican SP, George DJ, Reddi AH, Piantadosi S, Eisenberger MA, Simons JW. 1995. Identification of endothelin-1 in the pathophysiology of metastatic adenocarcinoma of the prostate. Nat Med 1:944-949.

Nelson JB, Chan-Tack K, Hedican SP, Magnuson SR, Opgenorth TJ, Bova GS, Simons JW. 1996. Endothelin-1 production and decreased endothelin $\mathrm{B}$ receptor expression in advanced prostate cancer. Cancer Res 56:663668.

Nelson JB, Nguyen SH, Wu-Wong JR, Opgenorth TJ, Dixon DB, Chung LW, Inoue N. 1999. New bone formation in an osteoblastic tumor model is increased by endothelin-1 overexpression and decreased by endothelin A receptor blockade. Urology 53:1063-1069.

Nielsen OS, Munro AJ, Tannock IF. 1991. Bone metastases: Pathophysiology and management policy. J Clin Oncol 9:509-524.

Nifuji A, Noda M. 1999. Coordinated expression of noggin and bone morphogenetic proteins (BMPs) during early skeletogenesis and induction of noggin expression by BMP-7. J Bone Miner Res 14:2057-2066.

Nifuji A, Kellermann O, Noda M. 1999. Noggin expression in a mesodermal pluripotent cell line $\mathrm{C} 1$ and its regulation by BMP. J Cell Biochem 73:437-444.

Oyajobi BO, Anderson DM, Traianedes K, Williams PJ, Yoneda T, Mundy GR. 2001. Therapeutic efficacy of a soluble receptor activator of nuclear factor kappaB-IgG $\mathrm{Fc}$ fusion protein in suppressing bone resorption and hypercalcemia in a model of humoral hypercalcemia of malignancy. Cancer Res 61:2572-2578.

Papapoulos SE, Hamdy NA, van der Pluijm G. 2000. Bisphosphonates in the management of prostate carcinoma metastatic to the skeleton. Cancer 88:3047-3053.

Parfitt AM. 2000. The mechanism of coupling: A role for the vasculature. Bone 26:319-323.

Patel KV, Schrey MP. 1995. Human breast cancer cells contain a phosphoramidon-sensitive metalloproteinase which can process exogenous big endothelin-1 to endothelin-1: A proposed mitogen for human breast fibroblasts. Br J Cancer 71:442-447.

Patel KV, Sheth HG, Schrey MP. 1997. Stimulation or endothelin-1 secretion by human breast cancer cells through protein kinase A activation: A possible novel paracrine loop involving breast fibroblast-derived prostaglandin E2. Mol Cell Endocrinol 126:143-151.

Pearse RN, Sordillo EM, Yaccoby S, Wong BR, Liau DF, Colman N, Michaeli J, Epstein J, Choi Y. 2001. Multiple myeloma disrupts the TRANCE/osteoprotegerin cytokine axis to trigger bone destruction and promote tumor progression. Proc Natl Acad Sci USA 98:11581-11586.

Percival RC, Urwin GH, Harris S, Yates AJ, Williams JL, Beneton M, Kanis JA. 1987. Biochemical and histological evidence that carcinoma of the prostate is associated with increased bone resorption. Eur J Surg Oncol 13:41-49.

Perkel VS, Mohan S, Baylink DJ, Linkhart TA. 1990. An inhibitory insulin-like growth factor binding protein (InIGFBP) from human prostatic cell conditioned medium reveals $\mathrm{N}$-terminal sequence identity with bone derived In-IGFBP. J Clin Endocrinol Metab 71:533-535.

Pirtskhalaishvili G, Nelson JB. 2000. Endothelium-derived factors as paracrine mediators of prostate cancer progression. Prostate 44:77-87.

Rabbani SA, Gladu J, Mazar AP, Henkin J, Goltzman D. 1997. Induction in human osteoblastic cells (SaOS2) of the early response genes fos, jun, and myc by the amino terminal fragment (ATF) of urokinase. J Cell Physiol 172:137-145.

Rana A, Chisholm GD, Khan M, Sekharjit SS, Merrick MV, Elton RA. 1993. Patterns of bone metastasis and their prognostic significance in patients with carcinoma of the prostate. Br J Urol 72:933-936.

Raval P, Hsu HH, Schneider DJ, Sarras MP, Jr., Masuhara K, Bonewald LF, Anderson HC. 1996. Expression of bone morphogenetic proteins by osteoinductive and nonosteoinductive human osteosarcoma cells. J Dent Res 75:1518-1523.

Reddi AH. 1997. Bone morphogenetic proteins: An unconventional approach to isolation of first mammalian morphogens. Cytokine Growth Factor Rev 8:11-20.

Roland S. 1958. Calcium studies in ten cases of osteoblastic prostatic metastasis. J Urol 79:339-342.

Roodman GD. 1996. Advances in bone biology: The osteoclast. Endocr Rev 17:308-332.

Rosol TJ. 2000. Pathogenesis of bone metastases: Role of tumor-related proteins. J Bone Miner Res 15:844-850.

Roudier M, Sherrard D, True L, Ott-Ralp S, Meligro C, MBerrie M, Soo C, Felise D, Quinn JE, Vessella R. 2000. Heterogenous bone histomorphometric patterns in metastatic prostate cancer. J Bone Miner Res 15S1:S567.

Sasaki T, Hong MH. 1993a. Endothelin-1 localization in bone cells and vascular endothelial cells in rat bone marrow. Anat Rec 237:332-337.

Sasaki T, Hong MH. 1993b. Localization of endothelin-1 in the osteoclast. J Electron Microsc (Tokyo) 42:193-196.

Schrey MP, Patel KV. 1995. Prostaglandin E2 production and metabolism in human breast cancer cells and breast fibroblasts. Regulation by inflammatory mediators. Br J Cancer 72:1412-1419.

Simonet WS, Lacey DL, Dunstan CR, Kelley M, Chang MS, Luthy R, Nguyen HQ, Wooden S, Bennett L, Boone T, Shimamoto G, DeRose M, Elliott R, Colombero A, Tan HL, 
Trail G, Sullivan J, Davy E, Bucay N, Renshaw-Gegg L, Hughes TM, Hill D, Pattison W, Campbell P, Boyle WJ, et al. 1997. Osteoprotegerin: A novel secreted protein involved in the regulation of bone density. Cell 89:309319 .

Solloway MJ, Dudley AT, Bikoff EK, Lyons KM, Hogan BL, Robertson EJ. 1998. Mice lacking Bmp6 function. Dev Genet 22:321-339.

Stern PH, Tatrai A, Semler DE, Lee SK, Lakatos P, Strieleman PJ, Tarjan G, Sanders JL. 1995. Endothelin receptors, second messengers, and actions in bone. $\mathrm{J}$ Nutr 125:2028S-2032S.

Suzuki A, Kaneko E, Maeda J, Ueno N. 1997. Mesoderm induction by BMP-4 and -7 heterodimers. Biochem Biophys Res Commun 232:153-156.

Szostak MJ, Kyprianou N. 2000. Radiation-induced apoptosis: Predictive and therapeutic significance in radiotherapy of prostate cancer (review). Oncol Rep 7:699706.

Taguchi Y, Yamamoto M, Yamate T, Lin SC, Mocharla H, DeTogni P, Nakayama N, Boyce BF, Abe E, Manolagas SC. 1998. Interleukin-6-type cytokines stimulate mesenchymal progenitor differentiation toward the osteoblastic lineage. Proc Assoc Am Physicians 110: $559-574$

Takuwa Y, Masaki T, Yamashita K. 1990. The effects of the endothelin family peptides on cultured osteoblastic cells from rat calvariae. Biochem Biophys Res Commun 170:998-1005.

Thalmann GN, Anezinis PE, Chang S-M, Zhau HE, Kim EE, Hopwood VL, Pathak S, Eschenbach ACv, Chung LWK. 1994. Androgen-independent cancer progression and bone metastasis in the LNCaP model of human prostate cancer. Cancer Res 54:2577-2581.

Thomas RJ, Guise TA, Yin JJ, Elliott J, Horwood NJ, Martin TJ, Gillespie MT. 1999. Breast cancer cells interact with osteoblasts to support osteoclast formation. Endocrinology 140:4451-448.

Tsuji K, Ito Y, Noda M. 1998. Expression of the PEBP2alphaA/AML3/CBFA1 gene is regulated by BMP4/7 heterodimer and its overexpression suppresses type I collagen and osteocalcin gene expression in osteoblastic and nonosteoblastic mesenchymal cells. Bone 22:87-92.

Urwin GH, Percival RC, Harris S, Beneton MN, Williams JL, Kanis JA. 1985. Generalised increase in bone resorption in carcinoma of the prostate. $\mathrm{Br} \mathrm{J}$ Urol 57 : $721-723$

Vinholes J, Coleman R, Eastell R. 1996. Effects of bone metastases on bone metabolism: Implications for diagnosis, imaging, and assessment of response to cancer treatment. Cancer Treat Rev 22:289-331.

Wan M, Shi X, Feng X, Cao X. 2001. Transcriptional mechanisms of BMP-induced osteoprotegrin gene expression. J Biol Chem 276:10119-10125.

Weber KL, Bolander ME, Rock MG, Pritchard D, Sarkar G. 1998. Evidence for the upregulation of osteogenic protein-1 mRNA expression in musculoskeletal neoplasms. J Orthop Res 16:8-14.

Wlosarski K, Reddi AH. 1987. Tumor cells stimulate in vivo periosteal bone formation. Bone Miner 2:185-192.

Wozney JM. 1992. The bone morphogenetic protein family and osteogenesis. Mol Reprod Dev 32:160-167.

Wrana JL. 2000. Regulation of Smad activity. Cell 100:189-192.

Yamaguchi A, Ishizuya T, Kintou N, Wada Y, Katagiri T, Wozney JM, Rosen V, Yoshiki S. 1996. Effects of BMP-2, BMP-4, and BMP- 6 on osteoblastic differentiation of bone marrow-derived stromal cell lines, ST2, and MC3T3-G2/ PA6. Biochem Biophys Res Commun 220:366-371.

Yamashita T, Yoshitake H, Tsuji K, Kawaguchi N, Nabeshima Y, Noda M. 2000. Retardation in bone resorption after bone marrow ablation in klotho mutant mice. Endocrinology 141:438-445.

Yanagisawa M, Kurihara H, Kimura S, Tomobe Y, Kobayashi M, Mitsui Y, Yazaki Y, Goto K, Masaki T. 1988. A novel potent vasoconstrictor peptide produced by vascular endothelial cells. Nature 332:411-415.

Yasuda H, Shima N, Nakagawa N, Mochizuki SI, Yano K, Fujise N, Sato Y, Goto M, Yamaguchi K, Kuriyama M, Kanno T, Murakami A, Tsuda E, Morinaga T, Higashio K. 1998a. Identity of osteoclastogenesis inhibitory factor (OCIF) and osteoprotegerin (OPG): A mechanism by which $\mathrm{OPG} / \mathrm{OCIF}$ inhibits osteoclastogenesis in vitro. Endocrinology 139:1329-1337.

Yasuda H, Shima N, Nakagawa N, Yamaguchi K, Kinosaki M, Mochizuki S, Tomoyasu A, Yano K, Goto M, Murakami A, Tsuda E, Morinaga T, Higashio K, Udagawa N, Takahashi N, Suda T. 1998b. Osteoclast differentiation factor is a ligand for osteoprotegerin/ osteoclastogenesis-inhibitory factor and is identical to TRANCE/RANKL. Proc Natl Acad Sci USA 95:35973602.

Yin J, Grubbs B, Cui Y, Weu-Wong J, Wessale J, Padley R, Guise T. 2000. Endothelin A receptor blockade inhibits osteoblastic metastases. J Bone Miner Res 15:S201.

Yoneda T. 1998. Cellular and molecular mechanisms of breast and prostate cancer metastasis to bone. Eur $\mathrm{J}$ Cancer 34:240-245.

Yorimitsu K, Moroi K, Inagaki N, Saito T, Masuda Y, Masaki T, Seino S, Kimura S. 1995. Cloning and sequencing of a human endothelin converting enzyme in renal adenocarcinoma (ACHN) cells producing endothelin-2. Biochem Biophys Res Commun 208:721727.

Zhang J, Dai J, Qi Y, Lin DL, Smith P, Strayhorn C, Mizokami A, Fu Z, Westman J, Keller ET. 2001. Osteoprotegerin inhibits prostate cancer-induced osteoclastogenesis and prevents prostate tumor growth in the bone. J Clin Invest 107:1235-1244.

Zimmerman LB, De Jesus-Escobar JM, Harland RM. 1996. The Spemann organizer signal noggin binds and inactivates bone morphogenetic protein 4. Cell 86:599-606. 